\title{
Main Quality Traits Analysis and Evaluation of Potato Germplasms
}

Xie Ruixia, Zhang Xiaochuan, Wu Linke®, Guo Zhiqian』, Zhang Guohui, Yu Bangqiang

Guyuan Branch of Ningxia Academy of Agriculture and Forestry Sciences, Guyuan, 756000, P.R. China

D. Corresponding author email: nxwlk@163.com; nxguozhiqian@126.com

Molecular Plant Breeding, 2021, Vol.12, No.28 doi: $10.5376 / \mathrm{mpb} .2021 .12 .0028$

Received: 16 Sep., 2021

Accepted: 24 Sep., 2021

Published: 20 Oct., 2021

Copyright (C) 2021 Xie et al., This article was first published in Molecular Plant Breeding in Chinese, and here was authorized to translate and publish the paper in English under the terms of Creative Commons Attribution License, which permits unrestricted use, distribution, and reproduction in any medium, provided the original work is properly cited.

Preferred citation for this article:

Xie R.X., Zhang X.C., Wu L.K., Guo Z.Q., Zhang G.H., and Yu B.Q., 2021, Main quality traits analysis and evaluation of potato germplasms, Molecular Plant Breeding, 12(28): 1-8 (doi: $10.5376 / \mathrm{mpb} .2021 .12 .0028$ )

\begin{abstract}
To improve the utilization efficiency of potato germplasm resources, the quality traits of 172 potato germplasms were analyzed. The results indicated that: (1) The variation coefficient of reducing sugar was the largest (66.67\%), and the range was $0.093 \sim 1.11 \mathrm{~g} / 100 \mathrm{~g}$; The variation coefficient of crude protein was larger $(21.11 \%)$, and the range was $1.12 \sim 3.57 \mathrm{~g} / 100 \mathrm{~g}$; The variation coefficient of dry matter was the smallest (12.85\%), and the range was $14.6 \% \sim 30.6 \%$. (2) The results of correlation analysis showed, it was very significantly negative correlation between reducing sugar and dry matter, crude protein or crude starch, a significantly negative correlation with vitamin $\mathrm{C}$, other quality traits were significantly positively correlated. (3) principal component analysis showed that the cumulative contribution rate of the four factors reached $97.75 \%$. as followed dry matter (47.98\%), reducing sugar (26.42\%), vitamin C (16.54\%) and crude protein (6.81\%). (4) All potato germplasms were classified into three groups at the level of $\mathrm{D}=23$. Class I had the highest dry matter and vitamin $\mathrm{C}$, class IV contained crude protein. The above conclusions will be beneficial to improve the utilization efficiency of potato germplasm and accelerate quality breeding.
\end{abstract}

Keywords Potato germplasm; Quality traits; Principle component analysis; Clustering analysis

Potato (Solanum tuberosum) is known as "second bread" and "underground apple" (Pan, 2019), which is an important grain and vegetable crop. The protein and vitamin $\mathrm{C}$ in tuber are 10 times that of apple. Potato is rich in dietary fiber, sylvite, lysine and tryptophan (Zhao, 2019), which is of great significance to ensure China's food security and people's balanced dietary nutrition. Since the staple food strategy was put forward, potato breeding has gradually changed from traditional fresh food type and starch processing type to special processing type, and the quality requirements of potato have become more detailed. The research on the evaluation and utilization of special processing quality traits has become the focus of new variety breeding (Wang et al., 2016; Qiu et al., 20119; Liu, 2018; Xu and Jin, 2017). To fully understand the main quality characteristics of germplasm resources and explore the utilization value of core germplasm resources of different quality types will be beneficial to improve the selection efficiency of parents and speed up the process of special quality breeding. Liu (2006) analyzed and determined the starch content of 382 introduced potato resources, and comprehensively evaluated the agronomic characters of 40 selected high starch resources. Luo et al. (2019) analyzed the contents of protein, vitamin C, starch and total amino acids in 6 samples of colored potatoes. Yu (2018) evaluated and analyzed the contents of reducing sugar, soluble sugar and starch as well as the color difference and texture traits of tuber and whole powder from 119 germplasm materials with rich genetic background and excellent comprehensive evaluation of phenotypic traits. Pan (2019) conducted correlation analysis, principal component analysis and cluster analysis on 8 quality traits of 53 materials and defined the use and classification of the tested varieties.

At present, most of the studies have focused on the evaluation and analysis of the quality of potato starch processing, potato chips processing and whole powder processing, but there are few data on the systematic analysis of quality traits. Therefore, correlation analysis, principal component analysis and cluster analysis were used to analyze the 5 main quality traits of 172 potato germplasm resources in this study, to clarify the differences of quality traits among different germplasm resources, and to screen the specific core germplasm resources that meet the requirements of different quality improvement parents, so as to provide technical reference for potato breeding. 


\section{Results and Analysis}

\subsection{Variation analysis of quality traits}

The coefficient of variation (CV) represents the discrete feature of traits, which can be used to analyze the genetic variation of different quality traits in germplasm resources. The $\mathrm{CV}$ of reducing sugar, crude protein, crude starch, vitamin $\mathrm{C}$ and dry matter of the 172 tested materials were significantly different (Table 1), with relatively rich genetic variation information. And the $\mathrm{CV}$ of the 5 quality traits is in the following order: reducing sugar $>$ crude protein $>$ crude starch $>$ vitamin $\mathrm{C}>$ dry matter. Among them, reducing sugar is $66.67 \%$, crude protein is $21.11 \%$, and dry matter is $12.85 \%$. The results showed that the diversity index of reducing sugar and crude protein was higher, which provided a good genetic basis for the improvement of reducing sugar and crude protein quality traits.

Table 1 Variations of main quality traits of tested potato resources

\begin{tabular}{llllllll}
\hline Trait & Mean & Max & Min & Variability & Variance & SD & CV $(\%)$ \\
\hline Dry matter $(\mathrm{g} / 100 \mathrm{~g})$ & 21.86 & 30.6 & 14.6 & 16 & 7.88 & 2.81 & 12.85 \\
Crude protein $(\mathrm{g} / 100 \mathrm{~g})$ & 1.99 & 3.57 & 1.12 & 2.45 & 0.17 & 0.42 & 21.11 \\
Vitamin c $(\mathrm{mg} / 100 \mathrm{~g})$ & 12.91 & 20.4 & 6.74 & 13.66 & 8.53 & 1.92 & 14.87 \\
Crude starch $(\%)$ & 15.7 & 23.22 & 8.56 & 14.66 & 5.68 & 2.39 & 15.22 \\
Reducing sugar $(\mathrm{g} / 100 \mathrm{~g})$ & 0.33 & 1.2 & 0.093 & 1.11 & 0.05 & 0.22 & 66.67 \\
\hline
\end{tabular}

\subsection{Correlation analysis of quality traits}

The results of correlation analysis of 5 quality traits showed that 6 pairs of quality traits were positively correlated (Table 2). Among them, dry matter and crude starch, dry matter and vitamin $\mathrm{C}$, vitamin $\mathrm{C}$ and crude protein, vitamin $\mathrm{C}$ and crude starch showed extremely significant positive correlation, and the correlation coefficient between dry matter and crude starch was the highest, which was 0.83 .4 pairs of quality traits showed a negative correlation. Among them, reducing sugar and crude protein, reducing sugar and dry matter, reducing sugar and crude starch showed extremely significant negative correlation, and the correlation coefficient between reducing sugar and crude protein was the highest (-0.63).

Table 2 Correlation coefficient among 5 quality traits of potato

\begin{tabular}{llllll}
\hline Trait & Dry matter & $\begin{array}{l}\text { Crude protein } \\
(\mathrm{g} / 100 \mathrm{~g})\end{array}$ & Vitamin C (mg/100 g) & Reducing sugar $(\mathrm{g} / 100 \mathrm{~g})$ & $\begin{array}{l}\text { Crude starch } \\
(\%)\end{array}$ \\
\hline Dry matter $(\mathrm{g} / 100 \mathrm{~g})$ & 1 & - & - & - & - \\
Crude protein $(\mathrm{g} / 100 \mathrm{~g})$ & $0.18^{*}$ & 1 & - & - & - \\
Vitamin c $(\mathrm{g} / 100 \mathrm{~g})$ & $0.25^{* *}$ & $0.24^{* *}$ & 1 & - & - \\
Reducing sugar $(\mathrm{g} / 100 \mathrm{~g})$ & $-0.33^{* *}$ & $-0.63^{* *}$ & $-0.18^{*}$ & 1 & - \\
Crude starch $(\mathrm{g} / 100 \mathrm{~g})$ & $0.87^{* *}$ & 0.08 & $0.37^{* *}$ & $-0.27^{* *}$ & 1 \\
\hline
\end{tabular}

Note: * and ** indicate significant level at $5 \%$ and $1 \%$ probability respectively

\subsection{Principal component analysis of quality traits}

It can be seen that the cumulative contribution rate of the first three eigencalues reached $90.94 \%$ (Table 3), indicating that the first three principal components contain most of the quality information of germplasm resources. The eigencalue of the first principal component is 2.4 with the contribution rate of $47.98 \%$. According to the eigenvector analysis of the 5 principal components (Table 4), the eigencalue of dry matter is the largest in the first principal component, followed by crude starch, crude protein and vitamin $\mathrm{C}$, indicating that dry matter has the greatest influence on the first principal component. Therefore, the dry matter factor is the first principal component. The eigencalue of the second principal component is 1.32 , contribution rate is $26.42 \%$, and comulative contribution rate is $74.4 \%$. In the second principal component, the eigencalue value of reducing sugar is the largest, followed by crude starch, dry matter and vitamin $\mathrm{C}$, indicating that reducing sugar makes the greatest contribution to the second principal component, so reducing sugar factor is the second principal component. The eigencalue of the third principal component is 0.83 , contribution rate is $16.54 \%$, and comulative contribution rate is $90.94 \%$. In the third principal component, the eigencalue value of vitamin $\mathrm{C}$ is the largest, followed by reducing sugar and crude protein, indicating that vitamin $\mathrm{C}$ makes the greatest contribution to the third principal component, so vitamin $\mathrm{C}$ is the third principal component. The eigencalue of the fourth principal 
component is 0.34 , the contribution rate is $6.81 \%$, and the cumulative contribution rate is $97.75 \%$. In the fourth principal component, the eigencalue of reducing sugar is the largest, followed by crude protein. As we known, reducing sugar is the second principal component factor, and crude protein has the greatest influence on the fourth principal component, so the crude protein factor is the fourth principal component. In a word, the traits of quality evaluation and analysis of potato germplasm resources were dry matter, reducing sugar, vitamin $\mathrm{C}$ and crude protein in turn.

Table 3 Principal component analysis of quality traits

\begin{tabular}{llll}
\hline Component & Eigencalue & Contribution rate (\%) & Comulative contribution rate (\%) \\
\hline 1st & 2.4 & 47.98 & 47.98 \\
2nd & 1.32 & 26.42 & 74.4 \\
3rd & 0.83 & 16.54 & 90.94 \\
4th & 0.34 & 6.81 & 97.75 \\
5th & 0.11 & 2.25 & 100 \\
\hline
\end{tabular}

Table 45 principal components of corresponding eigenvectors

\begin{tabular}{llllll}
\hline Trait & 1st & 2nd & 3rd & 4th & 5th \\
\hline Dry matter (g/100g) & 0.54 & 0.36 & -0.28 & 0.22 & -0.67 \\
Crude protein (g/100g) & 0.35 & -0.65 & 0.01 & 0.66 & 0.14 \\
Vitamin C (mg/100g) & 0.35 & 0.04 & 0.92 & -0.13 & -0.13 \\
Reducing sugar (g/100g) & -0.43 & 0.5 & 0.25 & 0.71 & 0.04 \\
Crude starch (\%) & 0.53 & 0.44 & -0.12 & 0.01 & 0.71 \\
\hline
\end{tabular}

\subsection{Cluster analysis of germplasm resources}

DPS16.05 software and Squared Euclidean distance were used to conduct systematic cluster analysis on 5 quality traits of 172 potato germplasm resources, including dry matter, reducing sugar, crude protein, vitamin $\mathrm{C}$ and crude starch. At the Euclidean distance of 23, 172 germplasm resources were divided into 4 groups (Figure 1). The average dry matter content and vitamin $\mathrm{C}$ content of 42 germplasm resources in the class I were the highest (Table 5). The dry matter content was $20.8 \sim 30.6 \mathrm{~g} / 100 \mathrm{~g}$, vitamin $\mathrm{C}$ content was $7.6 \sim 20.4 \mathrm{mg} / 100 \mathrm{~g}$, crude protein content was $1.35 \sim 3.57 \mathrm{~g} / 100 \mathrm{~g}$, reducing sugar content was $0.093 \sim 0.74 \mathrm{~g} / 100 \mathrm{~g}$, crude starch content was $14.68 \% \sim 23.22 \%$. This group includes domestic selected varieties (lines), CIP materials and other introduced materials, which can be used as improved parent materials for varieties with high dry matter and high vitamin $\mathrm{C}$. There are 52 resources in class II, the average contents of dry matter, crude protein and vitamin $\mathrm{C}$ were lower than those of class $\mathrm{I}$, in which the contents of dry matter, vitamin $\mathrm{C}$, crude protein, reducing sugar and crude starch were 19.7 27.9 g, 6.9 19.3 mg/100 g, 1.29 2.6 g, 0.093 0.52 g and 13.48\% 19.29\%, respectively. Class III contains 41 resources, and the highest average reducing sugar content was $0.61 \mathrm{~g} / 100 \mathrm{~g}$., in which reducing sugar content was $0.34 \sim 1.2 \mathrm{~g} / 100 \mathrm{~g}$, dry matter content was $14.6 \sim 23.9 \mathrm{~g} / 100 \mathrm{~g}$, vitamin C content was $6.74 \sim 14.9$ $\mathrm{mg} / 100 \mathrm{~g}$, crude protein content was $1.12 \sim 2.08 \mathrm{~g} / 100 \mathrm{~g}$, crude starch content was $8.56 \% \sim 17.04 \%$. This group can be used as parents for variety improvement by referring to other traits, such as 11 (Black beauty) can be used as an intermediate material for color potato variety improvement. Class IV contains 37 resources, and the average value of crude protein content is the highest, which was $2.27 \mathrm{~g} / 100 \mathrm{~g}$. Among them, crude protein content was $1.69 \sim 3.05 \mathrm{~g} / 100 \mathrm{~g}$, dry matter content was $14.6 \sim 22.6 \mathrm{~g} / 100 \mathrm{~g}$, vitamin C content was $7.8 \sim 17.8 \mathrm{mg} / 100 \mathrm{~g}$, reducing sugar content was $0.093 \sim 0.56 \mathrm{~g} / 100 \mathrm{~g}$, crude starch content was $10.96 \% \sim 16.22 \%$. This group showed high crude protein, which could be used as parents to improve high crude protein varieties.

\section{Discussion}

Broadening the genetic basis of potato and fully exploiting the utilization value of quality traits of germplasm resources are of great significance to the breeding of new potato varieties. According to different quality breeding needs, three quality types of resource groups were evaluated and selected. First one is suitable to be used as high dry matter and low reducing sugar resources for processing quality breeding parents or processing potatoes. 20 resources with dry matter content $\geq 25 \mathrm{~g} / 100 \mathrm{~g}, 20$ resources with reducing sugar content $<0.15 \mathrm{~g} / 100 \mathrm{~g}$, and 5 resources with two traits, namely, Root Potato 2, Root Potato 1, Root Potato 5, CIP396029.205 and Root Potato 4, respectively. Second one is suitable for starch processing varieties to select high starch resources of parents or 
intermediate materials. Among the 26 resources with crude starch content $\geq 18 \%$, Эалева had the highest crude starch content (23.22\%), followed by E15 (22.09\%). Third one with high vitamin C and high crude protein resources, which were suitable for breeding parents or intermediate materials of nutritional quality (fresh potato and food processing potato). 43 resources with vitamin $C$ content $\geq 15 \mathrm{mg} / 100 \mathrm{~g}, 20$ resources with crude protein content $\geq 2.5 \mathrm{~g} / 100 \mathrm{~g}$, and 4 resources with two traits, namely 'Ganyin2', 'CIP396236.2',' Spunta' and 'Flava', respectively.

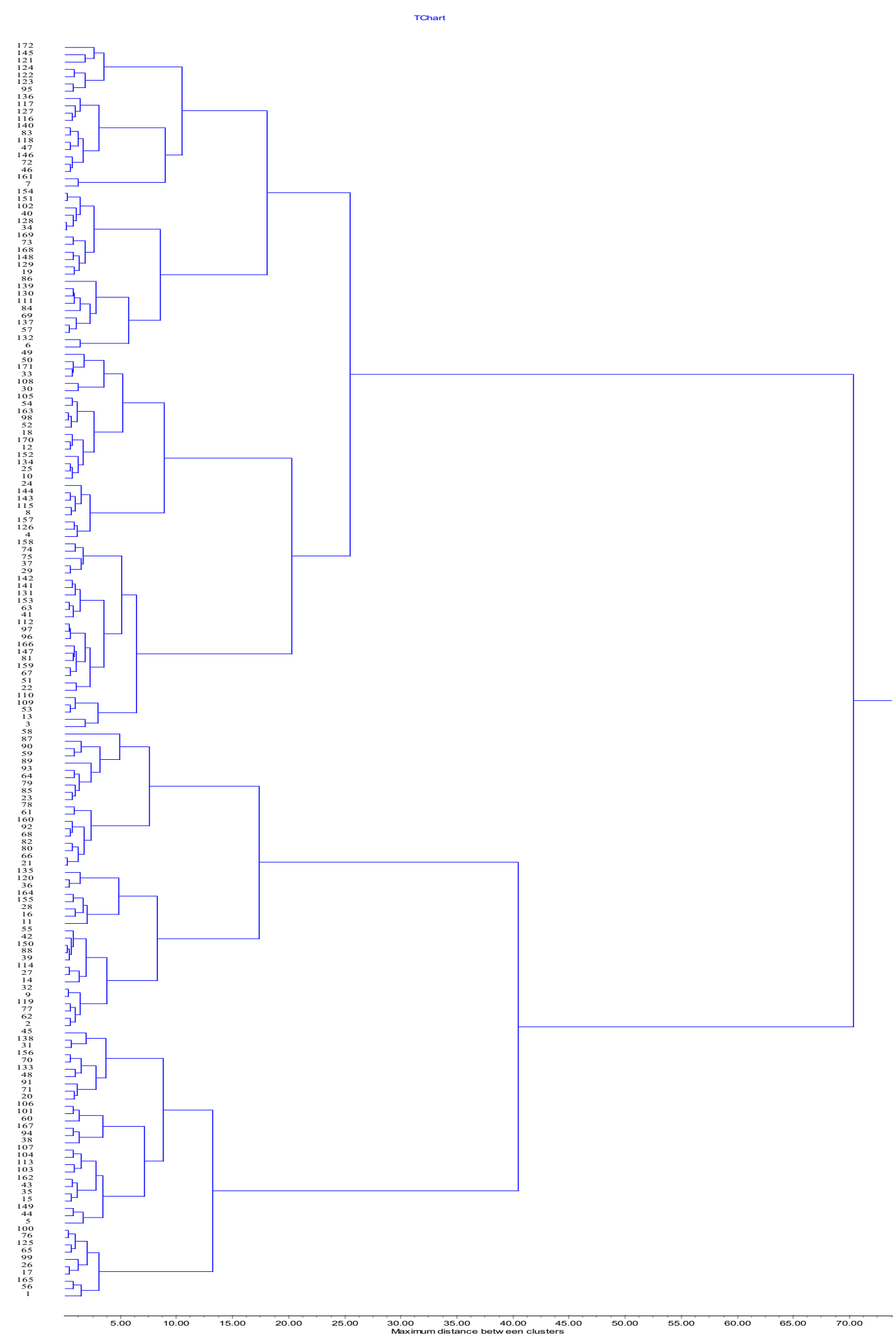

Figure 1 Dendrogram of cluster analysis of 172 potato germplasms 
Table 5 Average Values of 5 quality traits in 5 potato groups

\begin{tabular}{lllll}
\hline Trait & I & II & III & IV \\
\hline Dry matter $(\mathrm{g} / 100 \mathrm{~g})$ & 25.19 & 22.21 & 20.24 & 19.40 \\
Crude protein $(\mathrm{g} / 100 \mathrm{~g})$ & 2.13 & 1.97 & 1.60 & 2.27 \\
Vitamin C $(\mathrm{mg} / 100 \mathrm{~g})$ & 14.81 & 13.54 & 11.04 & 11.89 \\
Reducing sugar $(\mathrm{g} / 100 \mathrm{~g})$ & 0.26 & 0.24 & 0.61 & 0.24 \\
Crude starch $(\%)$ & 18.59 & 16.04 & 14.14 & 13.64 \\
\hline
\end{tabular}

In this study, it was found that there was a negative correlation between reducing sugar and dry matter, crude protein, crude starch and vitamin $\mathrm{C}$, and a positive correlation among dry matter, crude starch, crude protein and vitamin C, which was consistent with the conclusion of Pan (2019). There was a very significant positive correlation between crude starch content and dry matter content, and the correlation coefficient was 0.87 , indicating that crude starch is the main component of dry matter. Combined with the results of principal component analysis, if it is not the breeding of starch processing varieties, the crude starch content can be ignored, and the parents of other special processing varieties such as whole powder, fried slices, fried strips or cooking can be selected, mainly based on low reducing sugar and high dry matter, while referring to other agronomic and quality traits (Yu, 2018). There was a very significant negative correlation between reducing sugar content and crude protein content, with a correlation coefficient of 0.63 . This is mainly due to the Maillard reaction between reducing sugar and amino acids in the process of high temperature deep frying, resulting in brown matter, which leads to darker color after deep frying (Da Pereira and Da Costa, 1995; Liu, 2018). Therefore, the higher the crude protein content, the darker the color of French fries after high temperature deep frying.

The main quality traits of potato are mostly quantitative traits controlled by minor polygenes (Sun, 2003). Potato dry matter content and starch content are greatly affected by genetic factors (Pan, 2019), and the inheritance is mainly gene additive effect (Slattery et al., 2000). When breeding varieties with high dry matter or high starch, the parents or intermediate materials must be high dry matter or high starch materials on the basis of selecting other agronomic traits (Sun, 2010). In the breeding of low-reducing sugar varieties, the selection of parents or intermediate materials must consider the combining ability of parents on the basis of comprehensive consideration of other agronomic traits such as low-temperature storage resistance and inheritance of crude protein. Loiselle et al. (1990) found that combining ability of parents affected the process ability and color stability of potato chips.

\section{Materials and Methods}

\subsection{Test site}

The test site is located in Longde Guanzhuang Base of Guyuan Branch of Ningxia Academy of Agriculture and Forestry Sciences $\left(35^{\circ} 70^{\prime} \mathrm{N}, 106^{\circ} 18^{\prime} \mathrm{E}\right)$, with altitude of $2300 \mathrm{~m}$, annual average temperature of $8.4^{\circ} \mathrm{C}$, frost-free period of $135 \mathrm{~d}$, sunshine of $2988 \mathrm{~h}$ and average annual rainfall of about $603 \mathrm{~mm}$. And the soil of the test site is light black loessial soil, with $\mathrm{pH}$ value of $7.6 \sim 8.6$, content of organic matter of $2.69 \%$, hydrolyzed nitrogen of $96.9 \mathrm{~g} / \mathrm{kg}$, available phosphorus of $34.9 \mathrm{~g} / \mathrm{kg}$, and available potassium of $202 \mathrm{~g} / \mathrm{kg}$.

\subsection{Test materials}

172 potato germplasm resources, including 116 foreign materials and 56 domestic varieties (Table 6).

\subsection{Test methods}

From 2017 to 2018, the seeds were sown in numbered order at the Longde Guanzhuang base of Guyuan Branch of Ningxia Academy of Agriculture and Forestry Sciences without repetition. The planting area of each material is $40 \mathrm{~m}^{2}$, the row spacing is $90 \mathrm{~cm}$, and the plant spacing is $30 \mathrm{~cm} .7 \sim 14 \mathrm{~d}$ after harvest, crude protein (Kjeldahl determination was used in GB/T 5009.5-2010), crude starch (Polarimetry was used in NY/T 11-1985), reducing sugar (Direct titration was used in GB/T 5009.7-2008) and Vitamin C (Fluorometry was used in GB/T 5009.86-2003) were determined, and the samples to be tested were treated according to NY/T1303-2007(AppendixI). 
Table 6172 potato germplasms used in this experiment

\begin{tabular}{|c|c|c|c|c|c|}
\hline No. & Name & Origin & No. & Name & Origin \\
\hline 1 & Ailan 1 & China & 87 & CIP396008.104 & CIP \\
\hline 2 & Ba 72 South Yuxun & China & 88 & CIP396009.24 & CIP \\
\hline 3 & White Purple potato & China & 89 & CIP396009.258 & CIP \\
\hline 4 & Beishu 1 & China & 90 & CIP396012.266 & CIP \\
\hline 5 & Chuan 117 & China & 91 & CIP396018.241 & CIP \\
\hline 6 & Gan71-19-19 & China & 92 & CIP396026.101 & CIP \\
\hline 7 & Ganyin2 & China & 93 & CIP396026.103 & CIP \\
\hline 8 & Plateau 6 & China & 94 & CIP396027.205 & CIP \\
\hline 9 & Plateau 7 & China & 95 & CIP396029.205 & CIP \\
\hline 10 & Netherlands 15 & China & 96 & CIP396029.25 & CIP \\
\hline 11 & Black beauty & China & 97 & CIP396031.108 & CIP \\
\hline 12 & Red beauty & China & 98 & CIP396031.119 & CIP \\
\hline 13 & Tiger head & China & 99 & CIP396033.102 & CIP \\
\hline 14 & Ji Zhangshu 12 & China & 100 & CIP396034.103 & CIP \\
\hline 15 & Zhangshu 20 & China & 101 & CIP396034.268 & CIP \\
\hline 16 & Jinshu15 & China & 102 & CIP396036.201 & CIP \\
\hline 17 & Jinshu16 & China & 103 & CIP396037.215 & CIP \\
\hline 18 & Jinshu18 & China & 104 & CIP396038.101 & CIP \\
\hline 19 & Jinshu4 & China & 105 & CIP396038.107 & CIP \\
\hline 20 & Jinshu7 & China & 106 & CIP396043.226 & CIP \\
\hline 21 & Kexin 12 & China & 107 & CIP396046.105 & CIP \\
\hline 22 & Kexin4 & China & 108 & CIP396236.2 & CIP \\
\hline 23 & Landan & China & 109 & CIP396240.2 & CIP \\
\hline 24 & Liangshu 3 & China & 110 & CIP396240.23 & CIP \\
\hline 25 & Linshu16 & China & 111 & CIP396241.4 & CIP \\
\hline 26 & Longshu10 & China & 112 & CIP396244.17 & CIP \\
\hline 27 & Longshu 11 & China & 113 & CIP396247.15 & CIP \\
\hline 28 & Longshu 13 & China & 114 & CIP397077.16 & CIP \\
\hline 29 & Longshu6 & China & 115 & Pasqueflower & Germany \\
\hline 30 & Mengshu10 & China & 116 & Baiyin 1 & Unknow \\
\hline 31 & Mini potato & China & 117 & Atlantic & American \\
\hline 32 & Ningshu12 & China & 118 & Favorita & Holland \\
\hline 33 & Ninghu4 & China & 119 & Mira & Germany \\
\hline 34 & Ningshu8 & China & 120 & Baron Potato & American \\
\hline 35 & Qingshu168 & China & 121 & Root Potato 1 & Japan \\
\hline 36 & Qingshu2 & China & 122 & Root Potato 2 & Japan \\
\hline 37 & Tianshu12 & China & 123 & Root Potato 4 & Japan \\
\hline 38 & Tianshu9 & China & 124 & Root Potato 5 & Japan \\
\hline 39 & Tong7405-235 & China & 125 & Anti-epidemic White & Unknow \\
\hline 40 & Wei178 of 2 & China & 126 & A19 & Unknow \\
\hline 41 & Wu zao yangyu & China & 127 & Colmo & Holland \\
\hline 42 & Xiyutou & China & 128 & D52 & Unknow \\
\hline 43 & Xiazhai & China & 129 & D74 & Unknow \\
\hline 44 & Yanshu 9 & China & 130 & Desiree & Holland \\
\hline 45 & Miscellaneous single 38 & China & 131 & E13 & Unknow \\
\hline 46 & Early rose & China & 132 & E15 & Unknow \\
\hline 47 & Zhengshu 2 & China & 133 & E86-694 & Unknow \\
\hline 48 & Zoomlion Red & China & 134 & EBA & Holland \\
\hline 49 & Zhongshu 20 & China & 135 & F16 & Unknow \\
\hline 50 & Zhongshu 22 & China & 136 & Flava & Germany \\
\hline 51 & Zhongshu 5 & China & 137 & GB13-8 & Unknow \\
\hline 52 & Zhongshu 9 & China & 138 & $\mathrm{H} 29$ & Unknow \\
\hline 53 & Zhongshu D540 & China & 139 & Herbstgelbe & Germany \\
\hline 54 & Zhongshu D5682 & China & 140 & I46 & Unknow \\
\hline 55 & Center 24 & China & 141 & IDIAP92(381381.13) & Unknow \\
\hline 56 & Ziyun 1 & China & 142 & INIA310; Chucmarina(393371.58) & Unknow \\
\hline 57 & CIP378711.5 & CIP & 143 & $\mathrm{~J} 21$ & Unknow \\
\hline 58 & CIP391046.14 & CIP & 144 & $\mathrm{~K} 3$ & Unknow \\
\hline
\end{tabular}




\begin{tabular}{|c|c|c|c|c|c|}
\hline & & & & & Continued Table 6 \\
\hline No. & Name & Origin & No. & Name & Origin \\
\hline 59 & CIP393075.54 & CIP & 145 & K6 & Unknow \\
\hline 60 & CIP393077.159 & CIP & 146 & LK99 & Unknow \\
\hline 61 & CIP393077.54 & CIP & 147 & M12 & Unknow \\
\hline 62 & CIP393079.24 & CIP & 148 & Multa & Holland \\
\hline 63 & CIP393248.55 & CIP & 149 & N14 & Unknow \\
\hline 64 & CIP393280.57 & CIP & 150 & N8 & Unknow \\
\hline 65 & CIP393280.82 & CIP & 151 & NS51-5 & Unknow \\
\hline 66 & CIP393371.157 & CIP & 152 & NS78-1 & Unknow \\
\hline 67 & CIP393385.57 & CIP & 153 & NS78-21 & Unknow \\
\hline 68 & CIP395011.2 & CIP & 154 & NS78-78-1 & Unknow \\
\hline 69 & CIP395015.6 & CIP & 155 & NS880407 & Unknow \\
\hline 70 & CIP395017.14 & CIP & 156 & $\mathrm{P} 4$ & Unknow \\
\hline 71 & CIP395017.227 & CIP & 157 & P7 & Unknow \\
\hline 72 & CIP395017.229 & CIP & 158 & PAMPEANA-INTA & Unknow \\
\hline 73 & CIP395017.242 & CIP & 159 & S41956 & Unknow \\
\hline 74 & CIP395037.107 & CIP & 160 & SERRANITA(391691.96) & Unknow \\
\hline 75 & CIP395077.12 & CIP & 161 & Spunta & Holland \\
\hline 76 & CIP395084.9 & CIP & 162 & Tacan & Unknow \\
\hline 77 & CIP395096.2 & CIP & 163 & Tawa & American \\
\hline 78 & CIP395109.29 & CIP & 164 & Vester & Denmark \\
\hline 79 & CIP395109.34 & CIP & 165 & Victoria (381381.2) & Unknow \\
\hline 80 & CIP395111.13 & CIP & 166 & wilia & Holland \\
\hline 81 & CIP395112.19 & CIP & 167 & Zeisig & Germany \\
\hline 82 & CIP395112.32 & CIP & 168 & Голубиэна & Unknow \\
\hline 83 & CIP395112.36 & CIP & 169 & Малиновка & Unknow \\
\hline 84 & CIP395112.6 & CIP & 170 & Никунеенский & Unknow \\
\hline 85 & CIP395114.5 & CIP & 171 & Удача & Unknow \\
\hline 86 & CIP395123.6 & CIP & 172 & Эалева & Unknow \\
\hline
\end{tabular}

\subsection{Data analysis}

DPS16.5 data processing system and Excel2010 were used for statistical analysis. Euclidean distance and sum of squares of deviation were used for systematic cluster analysis.

\section{Authors' contributions}

XRX is the experimental designer and executor of this study. ZXC participated in data collation and drafted the manuscript. ZGH and YBQ participated in part of experiments. WLK and GZQ conceived of the project, directed the design of the study, data analysis, draft and revision. All authors read and approved the final manuscript.

\section{Acknowledgments}

The study was supported by the Special Project for Breeding New Varieties of Agricultural Characteristic Advantage Industries in Ningxia (2019NYYZ01-1), Ningxia Primary, Secondary and Tertiary Industry Integration Development Project (YES-16-0101), Agricultural Science and Technology Innovation Project of Ningxia Academy of Agricultural and Forestry Sciences (DWX2018034), and China Agriculture Research System of MOF and MARA.

\section{Reference}

Da Pereira A.S., and Da Costa, D.M., 1997, Quality and stability potato chips, Horticultura Brasileira, 15(1): 62-65

Liu X.C., 2006, Identification and comprehensive evaluation of high Starch content germplasm resources in potato, Zhongguo Shucai (China Vegetables), (S): $50-53$

Liu J., 2018, Assessment of processing traits and screening varieties from potato germplasm resources, Dissertation for Ph.D., Gansu Agricultural University, Supervisor: Zhang F., pp.15-68

Loiselle F., Tai G.C.C., and Christie B.R., 1990, Genetic components of chip color evaluated after harvest, cold storages and reconditioning, American Potato Journey, 67: 633-646 https://doi.org/10.1007/BF03043449

Luo W.B., Li H.W., Xu G.C., Xu Y.Q., Ji R.C., Qiu S.X., and Tang H., 2019, Introduction and Evaluation of Colored Potato Germplasms, Fujian Nongye Xuebao (Fujian Journal of Agricultural Sciences), 34(3): 278-283

Pan F., 2019, Evaluation of quality characters and utilization value of potato germplasm resources, Master Degree Dissertation, Northeast Agricultural University, Supervisor: Shi Y., and Zhang L.J., pp.16-37 
Molecular Plant Breeding 2021, Vol.12, No.28, 1-8 http://genbreedpublisher.com/index.php/mpb

Qiu J., Zhu H., Zhu D.Z., Sun J.M., 2019, Quality characteristics analyses of potatoes for different processing purposes, Zhongguo Malingshu (Chinese Potato Journal), 33(6): 372-378

Slattery C.J., Kavakli I.H., Okita T.W., 2000, Engineering starch for increased quantity and quality, Trends in Plant Science Reviews, 5(7): 291-298 https://doi.org/10.1016/S1360-1385(00)01657-5

Sun X.M., 2010, Segregation of fried and starch quality and combing ability of parents in potato, Thesis for M.S., Northeast Agricultural University, Supervisor: Chen Y.L., pp.48-60

Wang X.L., Ma Y.Q., and Sun J.M., 2016, China's potato consumption and its future prospect, Nongye Zhan wang (Agricultual Outlook), (12): 87-92

Xu J.F., and Jin L.P., 2017, Advances and perspectives in research of potato genetics and breeding, Zhongguo Nongye Kexue (Scientia Agricultura Sinica), 50(6): 990-1015

Yu B., 2018, Genetic diversity analysis of phenotypic traits and comprehensive assessment of tuber quality in introduced potato germplasm resources, Dissertation Ph.D., Gansu Agricultural University, Supervisor: Zhang J.L., pp.63-80 https://doi.org/10.3724/SP.J.1006.2018.00063

Zhao Z.Q., and Li X.L., 2019, The nutritional value and efficacy of potato, Zhongguo Guocai (China Fruit\& Vegetable), 39(1): 45-47 